\title{
Increasing Students' Global Mindset and Entrepreneurial Competencies through E-Consulting Projects
}

\author{
Amanda Bullough, University of Delaware, USA
}

AS SCHOLARS AND EDUCATORS IN THE FIELD of international business, we tend to find common ground on the value of helping our students increase their global mindset competencies. By "global mindset," I mean a set of competencies that impact the effectiveness with which a global leader influences people who are different from themselves, in a constantly changing, interdependent, complex, and ambiguous global world (Javidan, Teagarden, \& Bowen, 2010). As consumers and perpetuators of global business, I think it's fair to say that we also see the value in the development of new businesses. Global business development includes small and micro-sized businesses that are started all over the developing world, yet are grossly understudied and taught in business schools.

Experiential learning offers an extremely effective way for students to gain the exposure they need to dissimilar others, and to learn the skills and tools needed for new business development (Richardson \& Hynes, 2008). Tacit knowledge (knowledge-by-doing over time) cannot be underestimated for entrepreneurial and global business success, and an open learning environment that helps students to develop an ability and flexibility to adapt and modify plans can contribute to the development of tacit knowledge (Honig, 2004).

\section{BS Experiential learning offers an extremely effective way for} students to gain the exposure they need to dissimilar others, and to learn the skills and tools needed for new business development revising their client's business plan.

What if you have students who are interested in entrepreneurship but don't have a business idea? Maybe they are interested in starting a business some day in the future but don't have a business idea of their own at the point in time when they take your entrepreneurship course.

The way l've found to tackle both of these educational voids is through electronic-based consulting projects, where students are matched with real entrepreneurs in a foreign country and tasked with researching and

\section{Emerging Market Entrepreneurs Consulting Course}

Afewyears ago, I designed and implemented a consulting course, whereby I matched small teams of students with a small-business-owner client in a developing country. These clients were previously participants in one of the various business training programs conducted by Thunderbird for Good, an outreach office within the college that provides business training to nontraditional students from emerging markets. All of the entrepreneur-clients in the course were women, because it was through Thunderbird's women-entrepreneur training programs that I had access to clients in need, although the gender of the client is primarily beside the point.

The consulting course was designed for students who wanted to get more involved

But what if your students cannot, or won't, travel to another country? There are real-life circumstances that make global travel difficult or impossible for students at the time when they are enrolled in their university programs (e.g., job/employer limitations, birth of a baby, caring for a family member). I've had many colleagues at other universities tell me that their students are predominately from the local community or state, and enticing them to go abroad presents cognitive and financial barriers. The students and the members of their families are believed to have never obtained passports, or have shown little interest in the global world outside their locales. In my mind, this makes exposure to dissimilar others from different parts of the world all the more critical for these students. in Thunderbird's women entrepreneurs (WENT) programs, or in social business. In the course, students worked closely with me as they provided free consulting for their clients' business plans and business models. The goal was to conduct research and provide feedback that would help the business owner improve the quality of her business plan, and therefore help her to more successfully secure higher-level funding, like from USAID and other large funding sources.

My students applied their experiences and knowledge from other classes, learned how to write and review business plans, and worked in multicultural student teams. Students also learned the challenges that many developing country entrepreneurs face in their societies, like war, 
threats of kidnapping targeted at themselves and their family members, educational limitations, funding challenges, and limitations of physical and technological infrastructure and the supply of power. They also learned additional challenges that women entrepreneurs face in particular, like gender discrimination and work-family conflict. It is important for students to understand these challenges and learn from those who operate in such areas in order to become global leaders capable of promoting sustainable prosperity worldwide. Students also researched sources of capital to help launch or grow these businesses.

\section{Learning Objectives for the Course}

- Experience some of the issues that entrepreneurs, managers, expatriates, and consultants of organizations deal with in complex and quickly changing developing markets.

- Understand the challenges entrepreneurs facing in launching and operating businesses in their societies.

- Learn about the types of businesses started by women in developing countries and how to identify businesses that are critical for societal development.

- Gain experience in consulting with small business owners, share student expertise in business management, and learn from local entrepreneurs what running a business in other countries is like.

- Develop an understanding of matters that affect sustainable economic and social business development.

\section{Course Format}

This course was physically conducted in Glendale, Arizona. A few months before classes began, I contacted my colleagues in search of business-owner clients and business plans. I then narrowed that group of potential clients and emailed a select group of business owners. I began all of this long before the semester began, so that I had time to search for new clients if needed. As I received interest and commitments from business owners, I instructed them to await further contact from me and my students, and I gave them the dates of the course. I also required each business-owner client to electronically sign a participant contract, which was not legally binding, but served as a tangible good faith agreement among all sides. I also made clear that I could not promise that I would have a student team for all of my potential clients, and that this depended on the final enrollment in the course and student interest and experience. I then kept in touch and emailed the potential clients again closer to the start of the semester to ensure they were still interested and available.

When the semester began, I gave my students the options of available clients and instructed them to form teams. It was then up to the students in the classroom to form teams and work with a client whose business was of interest to them and would complement their skills and backgrounds. All of this was done with guidance from me as needed, although I mostly left it up to the students. Once the teams were formed and clients selected, I emailed the business owners and introduced them to their student consulting team. The students and their clients then developed an electronic relationship, which they nurtured and maintained via email, Skype, and conference call. The students and their client were responsible for identifying their preferred means of communication, based on communication costs, time zones and differences, and their schedules and availability. I intervened only as needed, which was minimal, although the students and business owners knew I was readily available if they needed me.

\section{Course Requirements}

Mini Case (20\% of final grade): Each student team wrote a mini case on their business-owner client. This was a 2-3 page paper (single spaced, 12-point font) that covered, in general: background information about their client, how the business idea came to their client and how she started the business, details about the business (e.g., type of business, number of employees, the kind of "want" or "need" the business satisfies for its customers) obstacles the business owner faced when launching the business or after the business was open and operating, and any major lessons the business owner learned.

Business Plan Revision and Recommendations (40\% of final grade): I worked closely with the program managers of the women entrepreneurs training programs at Thunderbird for Good to select worthwhile and appropriate business plans. I selected only business plans from business owners who I believed would be dependable and accessible via email for questions from my student-consultants. Because I unfortunately did not have the resources for ongoing translations, I selected only business-owner clients who spoke English, or had a dependable associate who spoke English. In their signed participant contract, these business also agreed to volunteer their time to other entrepreneurs who do not have access to this consulting.

By the end of the course, students revised the business plans based on research conducted online, with the university librarians, and in consultation with their client. I worked closely with each consulting team in order to: (1) guide the students for the very best possible learning opportunities, and (2) provide the most useful business plan and recommendations for the clients' businesses.

Final Presentation (10\% of final grade): Students presented their final projects at the end of the course, using PowerPoint or a similar presentation program. Students were graded on their professional demeanor and their success in leaving the audience with a clear understanding of the business idea and the final conclusion of its feasibility. Students were told to present to the class in a professional manner, as if in a real-life business meeting, meaning that they should dress appropriately and elaborate on the content on each slide. They were given a 30-minute time limit: 20-25 minutes to present, 5-10 minutes for questions and feedback. 
Personal Essay (10\% of final grade): Students maximized their learning in this course by writing a short and personal essay. It is recommended, although not required, that each student take some time to reflect on what they learned after each class and team meeting, and write it down. Each student wrote a 2-3 page personal essay (single spaced, 12-point font) that covered, in general: what they learned during each class or meeting, any new insights (into women's entrepreneurship, developing countries, and entrepreneurship), how they could use this learning or these insights to become a more effective leaders, what they learned that will help them advise developing entrepreneurs in the future, and/ or what they learned that will help them advise organizations working to promote entrepreneurship in developing areas.

Team Evaluation (10\% of final grade): Team evaluations were due at the end of the class, after the students completed all the required work, and submitted with their final business plan projects.

\section{Proud Professor Connects Thunderbird Students with Women Entrepreneurs}

In my academic career, I have honestly never been more proud! Through this course, I was able to connect my research interests, my interest in working with women for economic development, and my teaching, all together in a worthwhile way. This course connected Thunderbird MBA and MA students from various different backgrounds themselves, with entrepreneurs from developing countries, who had high growth potential businesses (e.g., a high-end embroidery textiles business in Afghanistan, a natural skin care products company in Indonesia, and a luxury/indigenous massage spa in Malaysia). My students impressed me, even more than I hoped they would.

I knew all along what kind of impact we would make through this course for our business-owner clients. I also knew that each student would finish the course with new insights and skills. What I didn't realize fully was the impact the experience would have on their views of others in the world around them. I have always stood in awe of the women entrepreneurs I work with, because they often face discrimination and discouragement throughout their entire lives, and yet they persevere in the most astounding ways. Even in the most hospitable of developing country circumstances, they face structural barriers. They don't fear negativity, they don't fear failure, and they don't let fear for their lives stop them. I have been moved by learning that my business students are humbled by these women as well, and have learned as much from them as they've given through this course.

\section{Highlights from What My Students Shared With Me}

This was a course, for all practical purposes, on business plans, but my students noted they also received a refresher course on product analysis and competition, effective marketing strategies in a foreign and developing country, distribution methods, and how to achieve brand awareness in a completely unfamiliar culture. From this course, without even leaving our campus, the students told me that they realized the procedural and strategic differences associated with trying to sell a product in an unfamiliar culture and business environment, in the real world, rather than just in theory.

They also learned that there are structural limitations that women face, even in the most positive business environments, like not being allowed to own their businesses outright without a man owning at least some portion, even if he's not a functioning member of the business's start-up or operations. One student commented, "Being a woman in a developing country almost always adds an additional layer of complexity to being an entrepreneur."

Another commented, "[I learned that] when I start my business in the future, although many factors of business success vary according to region (for example, marketing and distribution), there are certain universal things that must exist in order for a business to succeed, such as organization, a good grasp of the numbers, making sure not to grow too quickly before a solid base is established, and the belief that you have something special and different to offer."

As a result of this class, students felt that they became more effective leaders because they now know what questions to ask, what to look for, and the types of recommendations their clients may need. They also learned more about how to advise organizations working to promote women's entrepreneurship in developing countries. Grants that support the advancement of women's businesses are important in developing countries, but consulting on the effectiveness of the business model is also critical for the profitability and growth of the business.

Our male students in the class commented that they now have a better appreciation and understanding of what women in developing countries face with regard to starting and running businesses. They feel that this understanding positions them better for future work within emerging economies.

Several students noted a particularly important lesson: when working to promote entrepreneurship in developing countries, it is necessary to have a local expert from the region.

However, they also learned that you cannot rely on the client to give an accurate idea of the problems his or her company faces. It often takes an outsider with a keen eye to uncover all the elements that need attention in a business - an exercise required in order to write a proper business plan. There may be underlying, root causes for why a business isn't profitable, for example, that have little to do with the problem the business owner initially identified. One student advised consultants to "ask for information in a variety of ways and in multiple contexts, particularly if English is not the first language of the client. Ask politely to avoid badgering the client, but in different ways so that you can obtain the information needed for analysis." Students had questions prepared, but they had not prepared for the possibility that the client would be unfamiliar with some terminology. So they carefully and respectfully explained what information was needed, how it might appear in the business owner's records, and how it would add value to her business 
plan. Approaching the client with reasons for the requests made the client more responsive and eager to learn more about the process.

In another example, when one student consulting team asked their client about competitors, they were initially told that the business had no competition. Then, at a later meeting, the client mentioned that the success of her company inspired other individuals to enter the spa industry. So, the students again asked whether these spas were competitors, and were told that they were not. It was only once the team did an analysis of the competitive landscape themselves, drew conclusions from this analysis, and presented them to their client, that the business owner then gave the students a well-researched competitor analysis that she made previously and had been using as a basis for her pricing structure and positioning strategy. It appeared that their client did not clearly understand what a "competitor" was, so she was not able to give my students the information they needed, until they had a conversation under a different context about pricing and what other similar businesses charged. Their business-owner client figured that because these other businesses served a slightly different clientele, they were therefore not competitors. This part of the conversation then led to a whole new conversation about the types of customers the business was targeting and why, pricing, the potential untapped market share, and more.

This example shows that the students learned the frustrating interactions that happen sometimes with clients. They also learned that during a short consulting project, unrealized miscommunication can cause significant delays in learning critical details. They learned how important it was to get to know the client and how she communicated, in order to make the best use of time on the project. They made simple changes to Skype sessions and emails and dramatically increased the amount of data the client provided.

The students also learned that in some countries, people are much less supportive of women in business because their families fear for their security, even though a thriving business could benefit the community. The lack of business associations, education, infrastructure, and security can be crippling for the development of the private sector, and subsequently the economic development of the country. Students learned that when dealing with people in locations plagued with severe adversity, people from developed countries must be able to exercise patience and try to understand that operations in these places may not function as smoothly as we expect.

As a result of the course, my students view these developing country business owners as strong forces to be embraced and encouraged for the development of their countries. A valuable life-long lesson my students learned was that they have as much to learn from people in developing countries as they have to offer. In the case of women entrepreneurs specifically, when the students tried to put themselves in their position and think of how determined they would be after discouragement, roadblocks, closed doors, and failed attempts throughout their lives, they have a new-found respect for just how strong and resilient these women are. This seems to have left some of the students humbled by how fortunate they have been in their own upbringing. They were moved by how the women we worked with were not only motivated to generate an income for their own personal households, but they also quite passionately want to do what they can to change their whole country and other people's lives through their businesses.

Some of the students received feedback from the women after the course was completed, saying how helpful their ideas, questions, and recommendations were. It is my hope that these students continue to feel very proud of their work and dedication to their clients!

\section{References}

Honig, B. 2004. Entrepreneurship education: Toward a model of contingency-based business planning. Academy of Management Learning and Education, 3(3): 258-273.

Javidan, M., Teagarden, M., \& Bowen, D. 2010. Managing yourself: Making it overseas. Harvard Business Review, 88(4): 109-113.

Richardson, I., \& Hynes, B. 2008. Entrepreneurship education: towards an industry sector approach. Education + Training, 50(3): 188-198.

Amanda Bullough (bullough@udel.edu) is an assistant professor of management at the University of Delaware. Prior to this, she was an Assistant Professor of Entrepreneurship and Leadership at Thunderbird School for Global Management in Arizona. Her current research includes entrepreneurship in war zones and under adverse conditions, and global mindset and leadership in teams. She teaches organizational behavior, entrepreneurship, and international business and has published articles in well-regarded journals. She received her PhD degree from FIU. 